\title{
PENGARUH PARTISIPASI MASYARAKAT, KAPASITAS APARATUR GAMPONG DAN PENGAWASAN BADAN PERMUSYAWARATAN GAMPONG TERHADAP KINERJA PENGELOLAAN ALOKASI DANA GAMPONG (STUDI PADA KECAMATAN GEUMPANG, MANE, DAN TANGSE KABUPATEN PIDIE)
}

\author{
Rizky Ananda Sari ${ }^{1}$, Endang Surasetyo Ningsih ${ }^{* 2}$ \\ ${ }^{1,2}$ Program Studi Akuntansi Fakultas Ekonomi Universitas Syiah Kuala \\ e-mail: rizky.anandasari@gmail.com ${ }^{1}$, endangsnt @ unsyiah.ac.id ${ }^{* 2}$ \\ * Corresponding Author
}

\begin{abstract}
This study aims to examine the effect of community participation, the capacity of the village apparatus, and the supervision of the village consultative department on the performance of village fund allocation management in Geumpang, Mane and Tangse sub-districts of Pidie District. The primary data used is obtained from closed questionnaire using Likert scale. There are 185 samples of data that become the object of research. Hypotheses were tested using multiple linear regression analysis. The results showed that simultaneously the variables of community participation, the capacity of the village apparatus, and the supervision of the village consultative department had an effect on the performance of the village fund allocation management. Partially, the result of the research indicates that (1) the participation of the community influences the performance of the management of the village fund allocation, (2) the capacity of the village apparatus affects the management performance of the village fund allocation and (3) the supervision of the village consultative department affects the performance of the village fund allocation management.
\end{abstract}

Keywords: Community Participation, Capacity, Village Apparatus, Supervision, Management Performance, Village Fund Allocation

\section{Pendahuluan}

Guna meningkatkan pelayanan dan kesejahteraan masyarakat, Pemerintah Pusat memberikan dana perimbangan daerah sebagai sumber pendapatan daerah. Dana tersebut diberikan oleh pemerintah pusat yang berasal dari Anggaran Pendapatan dan Belanja Negara (APBN) untuk mendukung pelaksanaan kewenangan pemerintah daerah dalam mecapai tujuan (Widjaja, 2002:23). Setiap tahun dalam APBN telah ditetapkan Dana Alokasi Umum (DAU) bagi semua daerah kabupaten/kota. Suatu Daerah Provinsi tertentu ditetapkan berdasarkan jumlah Dana Alokasi Umum untuk suatu daerah provinsi yang ditetapkan dalam APBN dikalikan dengan rasio bobot daerah provinsi yang bersangkutan, terhadap jumlah bobot seluruh provinsi. Porsi Daerah Provinsi ini merupakan persentase bobot daerah provinsi yang bersangkutan terhadap jumlah bobot semua daerah provinsi di seluruh Indonesia (Halim, 2012:114).

Mengatasi ketimpangan fiskal keuangan antara pemerintah pusat dan ketimpangan horizontal antar pemerintah daerah diperlukan karena ketidakmerataan sumber daya yang ada pada masing-masing daerah, Pemerintah Pusat dan Pemerintah Daerah menciptakan sebuah program yang diberi sebutan Alokasi Dana Desa (ADD) atau Alokasi Dana Gampong (ADG) untuk daerah Aceh. ADG merupakan bantuan dana untuk membiayai dan mendorong pelaksanaan program pemerintah desa. Sesuai dengan Peraturan Menteri Dalam Negri No. 37 Tahun 2007 tentang pedoman pengelolaan keuangan desa di dalam pasal 18 yang menyatakan bahwa "Alokasi Dana Desa (ADD) berasal dari bagi hasil pajak dan Aggaran Pendapatan dan Belanja Daerah (APBD) Kabupaten/Kota yang bersumber dari dana perimbangan keuangan pusat dan daerah yang diterima 
oleh pemerintah kabupaten/kota untk desa paling sedikit $10 \%$."

Guna melihat tercapai atau tidaknya tujuan penggunaan dana gampong, perlu adanya tinjauan atas kinerja pengelolaan keuangan gampong. Kinerja merupakan level prestasi pelaksanaan suatu program atau kegiatan dalam merealisasikan saran, tujuan, visi, dan misi organisasi yang tertuang dalam perencanaan jangka panjang organisasi (Munti dan Fahlevi, 2017). Meningkatkan kinerja gampong maka secara tidak langsung juga meningkatkan kinerja pemerintah daerah. Kinerja dapat diukur dengan menggunakan empat indikator yaitu efisiensi, efektivitas, ekonomis, dan pelaporan yang memadai (Mardiasmo, 2009).

Belakangan ini, ada beberapa kasus mengenai ADG yang seharusnya dapat menjadi tolak ukur kinerja aparatur desa, salah satunya adalah telatnya menyampaikan Laporan PertanggungJawaban (LPJ). Sebagaimana kita ketahui bahwa LPJ merupakan dokumen tertulis yang disusun dengan tujuan memberikan laporan tentang pelaksanaan kegiatan dari suatu unit organisasi kepada unit organisasi yang lebih tinggi atau sederajat dan diserahkan setiap 6 bulan sekali. Dalam surat kabar Serambi Indonesia pada tanggal 26 Juni 2014, terdapat 164 lembaga dan 4 Kabupaten yang belum menyerahkan LPJ terhitung sejak tahun 2013. Selain itu, pada tanggal 10 April 2018, beredar kabar bahwa dari 6.497 gampong di Aceh hanya 430 gampong saja yang dapat menerima dana tahap selanjutnya dikarenakan 6.067 gampong lainnya belum menyerahkan LPJ.

Dana yang akan disalurkan akan berguna untuk kegiatan atau program gampong dan apabila tersendatnya pemasukan dana maka hal itu akan mempengaruhi kinerja desa itu sendiri. Oleh karena itu, penelitian ini akan menelaah faktor yang mempengaruhi kinerja pengelolaan ADG. Faktor pertama yang akan menjadi tinjauan dalam penelitian ini adalah partisipasi masyarakat.

Menurut Isbandi (2007:27), partisipasi masyarakat adalah keikutsertaan masyarakat dalam proses pengidentifikasian masalah dan potensi yang ada di masyarakat, pemilihan dan pengambilan keputusan tentang alternatif solusi untuk menangani masalah, pelaksanaan upaya mengatasi masalah, dan keterlibatan masyarakat dalam proses mengevaluasi perubahan yang terjadi. Dalam penelitian Kartika (2012), dikemukakan bahwa partisipasi masyarakat dalam mengelola $\mathrm{ADG}$ adalah hak bagi warga untuk menyuarakan, mengakses, dan mengontrol program ADG yang ada di desanya. Kebijakan ADG sangat relevan dengan perspektif yang menempatkan desa sebagai basis partisipasi, dikarenakan desa berhadapan langsung dengan masyarakat dan kontrol masyarakat lebih kuat maka untuk mencapai kinerja pengelolaan ADG yang signifikan diperlukan adanya partisipasi dari masyarakat desa.

Faktor kedua yaitu kapasitas aparatur gampong, dimana aparatur gampong baik memiliki penguasaan pengetahuan, keterampilan, dan wawasan yang diperoleh melalui pendidikan, latihan, belajar serta pengalaman, sedangkan tingkat kempuan yang harus dimiliki oleh aparatur desa harus mencakup (1) Kemampuan dasar, seperti pengetahuan tentang regulasi desa, pengetahuan tentang dasar-dasar pemerintahan desa, dan pengetahuan tentang tugas pokok; (2) Kemampuan manajemen, seperti manajamen Sumber Daya Manusia (SDM), managemen pelayanan publik, managamen aset serta manajemen keuangan; (3) Kemampuan kemampuan teknis, yang meliputi penyusunan administrasi desa, penyusunan perencanaan pembangunan, penyusunan anggaran, penyusunan perdes, dan pelayanan publik (Asrori, 2014). Berdasarkan penjelasan tersebut, kapasitas aparatur gampong dipercaya sangat di perlukan untuk merealisasikan dan meningkatkan kinerja atas program yang telah di rencanakan oleh pemerintah desa.

Faktor ketiga yaitu pengawasan Badan Permusyawaratan Gampong (BPG). Siagian (2010: 319), menyatakan bahwa pengawasan merupakan kegiatan untuk menyakinkan dan menjamin bahwa pekerjaan-pekerjaan dilakukan sesuai dengan rencana yang telah ditentukan, kebijakan-kebijakan yang telah digariskan, dan perintah-perintah yang telah diberikan dalam rangka pelaksanaan kerja untuk mencapai target yang telah ditentukan. Pengawasan merupakan salah satu cara untuk membangun dan menjaga kepercayaan masyarakat terhadap kinerja pemerintahan dengan menciptakan suatu sistem pengawasan yang efektif, baik pengawasan internal maupun pengawasan eksternal. Berdasarkan hasil penelitian yang telah dilakukan Putra (2013) mengenai Pengawasan BPG dalam pengelolaan ADG di Gampong Suliliran Baru Pasir Belekong Kabupaten Paser, menyatakan bahwa pengawasan BPG masih kurang optimal dalam 
realisasi dana ADG. Pengawasan kegiatan pemberdayaan masyarakat yang dilakukan banyak tanpa disertai acuan atau tolak ukur pengawasan, yaitu rencana anggaran biaya, sehingga tindakan penyelewengan yang terjadi juga tidak dapat terindikasi.

Latar belakang sebelumnya membahas mengenai fenomena dan faktor-faktor yang mungkin mempengaruhi kinerja pengelolaan alokasi dana gampong. Berdasarkan penjelasan tersebut penelitian ini ingin mengungakapkan lebih jauh faktor-faktor yang berkaitan dengan kinerja pengelolaan alokasi dana gampong. Dikarenakan fenomena yang disebutkan sebelumnya berasal dari desa di Aceh maka penelitian ini menjadikan Kecamatan Geumpang, Mane, dan Tangse yang merupakan desa di salah satu kabupaten di Aceh yaitu Kabupaten Pidie. Terdapat 37 Gampong dari 3 kecamatan yang akan menjadi objek penelitian.

\section{Kerangka Pemikiran Dan Hipotesis}

\section{Pengaruh Partisipasi Masyarakat terhadap Kinerja Pengelolaan Alokasi Dana Gampong}

Masyarakat Gampong merupakan bagian dari sasaran pembangunan nasional. Guna menunjang kesejahteraan masyarakat gampong, gampong mendapatkan dana bagi hasil dari pemerintah kabupaten sebagai bentuk pendapatan gampong yang berbentuk Anggaran Dana Gampong. Kebijakan ADG memberikan kewenangan kepada gampong untuk mengelola keuangannya sendiri. Pengelolaan ADG dilaksanakan secara partisipatif yaitu dengan melibatkan masyarakat secara aktif didalam perencanaan, pelaksanaan, dan evaluasi. Singkatnya, partisipasi masyarakat menjadi titik strategis dalam pengelolaan ADG.

Partisipasi masyarakat pada dasarnya berperan penting didalam menciptakan keadaan yang lebih adil, partsipatif, dan akuntabel juga merupakan salah satu upaya untuk membangun kembali kepercayaan masyarakat terhadap pemerintah, khususnya pada level pemerintahan gampong. Suwandi (2015), menemukan bahwa tingkat partisipasi masyarakat dalam pelaksanaan musyawarah gampong cukup tinggi, namun dalam pengelolaannya pengawasan yang dilakukan oleh masyarakat belum terjadi secara langsung. Hal tersebut terjadi karena kurangnya pemahaman masyarakat sehingga perlu adanya sosialisasi dan transparansi penggunaan dana ADG dari pemerintah.

Lubis (2011) melakukan penelitian yang berjudul Pengaruh Otonomi Gampong Terhadap Partisipasi Masyarakat Dalam Pembangunan Gampong (Studi Pada Gampong Pulau Jambu, Kecamatan Kampar, Kabupaten Kampar, Provinsi Riau). Hasil penelitian menunjukkan bahwa ada pengaruh positif antara otonomi gampong terhadap partisipasi masyarakat dalam pembangunan gampong.

\section{Pengaruh Kapasitas Aparatur Gampong terhadap Kinerja Pengelolaan Alokasi Dana Gampong}

Aparatur merupakan salah satu faktor terpenting sebagai penunjang pemerintah. Tugas utama dari aparatur adalah sebagai pelayanan masyarakat dan membantu pemerintah untuk mencapai tujuan pemerintahan. Tanpa adanya aparatur, pemerintah tidak akan mampu menjalankan fungsinya sebagai pemberi pelayanan. Mengingat begitu pentingnya peran aparatur maka perlu adanya peningkatan kualitas dari aparatur itu sendiri baik melalui pengembangan aparatur dengan pelatihan maupun dengan berbagai hal lainnya (Asrori, 2015).

Terlepas dari kenyataan masih banyaknya aparatur gampong yang kompetensinya masih kurang memadai akibat prasyarat pendidikan dan kurangnya pendidikan dan pelatihan yang diberikan kepada para aparatur gampong, maka dalam rangka implementasi undang-undang gampong yang memberikan kewenangan cukup besar kepada pemerintahan gampong untuk mengelola pemerintahan dan pembangunan, perlu adanya upaya-upaya peningkatan kualitas aparatur gampong sebagai sumber daya manusia agar mampu melaksanakan tugas-tugas yang diemban pemerintah gampong dengan baik (Suwondo, 2013).

Ilmu manajemen personalia membahas mengenai upaya peningkatan kualitas sumber daya manusia disebut pengembangan karyawan. Tujuan pengembangan karyawan adalah untuk memperbaiki efektifitas kerja karyawan dalam mencapai hasil-hasil kerja yang telah ditetapkan (Heidjarachman, 2008:74). Aparatur gampong yang kurang memiliki pengetahuan dan keterampilan tentang bidang tugasnya akan mengalami kesulitan dan kelambatan dalam bekerja, yang berakibat pada pemborosan bahan, waktu, dan biaya. 
Sumber daya manusia harus terus dikembangkan dalam upaya mendukung pengembangan kemampuan aparatur pemerintah sebagai wujud melaksanakan pembangunan dalam memberikan pelayanan kepada masyarakat. Pengembangan Sumber daya sangat penting dilakukan sebagaimana diungkapkan (Soedarmayanti, 2007:163) pengembangan dan pelatihan merupakan usaha mengurangi atau menghilangkan terjadinya kesenjangan antara kemampuan karyawan dengan yang dikehendaki organisasi. Pengembangan perangkat gampong merupakan keharusan yang harus dilakukan secara terus-menerus, mengikuti perkembangan masyarakat, kemajuan teknologi, dan bertambahnya tugas serta wewenang yang harus diemban.

Penelitian Suwondo et al., (2013) menyatakan bahwa semakin sering aparatur gampong diberikan pelatihan, maka semakin baik pula kinerja aparatur gampong dalam mengelola keuangan gampong dikarenkan aparatur gampong sudah menerima pembelajaran dan pelatihan untuk mengembangkan kemampuan diri baik secara teoritis maupun teknis.

\section{Pengaruh Pengawasan BPG terhadap Kinerja Pengelolaan Alokasi Dana Gampong}

Pemerintah provinsi wajib mengkoordinasikan pemberian dan penyaluran alokasi dana gampong dari kabupaten/kota kepada gampong (Nurcholis, 2011:90). Selain itu, pemerintah kabupaten/kota dan kecamatan juga wajib membina dan mengawasi pelaksanaan dan pengelolaan keuangan gampong.

Peran BPG dalam pengelolaan dana gampong antara lain menyampaikan gagasan mengenai pengelolaan dana gampong sebagai wujud penampungan aspirasi masyarakat sebagai penentu prioritas pelaksanaan pengelolaan dana gampong dengan pertimbangan kepala gampong. Pengawasan dan pemantauan dalam mengelolaan dana gampong dilakukan BPG secara langsung dan berjalan sesuai apa yang diharapkan bersama kepala dan perangkat gampong, serta kelompok masyarakat dari awal sampai selesai.

BPG juga wajib menyampaikan laporan administrasi keuangan BPG yang bersumber dari anggaran pendapatan dan belanja gampong kepada kepala gampong selaku pemegang kekuasaan pengelolaan keuangan gampong. BPG wajib menyampaikan laporan karena BPG juga menggunakan dana dari APBG. Oleh karena itu, dalam rangka akuntabilitas BPG juga membuat laporan penggunaan keuangannya. Laporan administrasi keuangan BPG disampaikan secara tertulis.

Kenyataannya pengelolaan dana gampong menunjukkan bahwa BPG belum optimal dalam melaksanakan peran serta fungsinya sebagai penyelenggara pemerintahan gampong dalam hal pengelolaan dana gampong. Hasil penelitian yang telah dilakukan Putra (2013) mengenai Pengawasan BPG dalam pengelolaan ADG di Gampong Suliliran Baru Pasir Belekong Kabupaten Paser, menyatakan bahwa pengawasan BPG masih kurang optimal dalam realisasi dana ADG. Pengawasan kegiatan pemberdayaan masyarakat yang dilakukan banyak tanpa disertai acuan atau tolak ukur pengawasan yaitu Rencana Anggaran Biaya, sehingga tindakan penyelewengan yang terjadi juga tidak dapat terindikasi. Skema kerangka pemikiran dapat dilihat pada gambar 2.1.

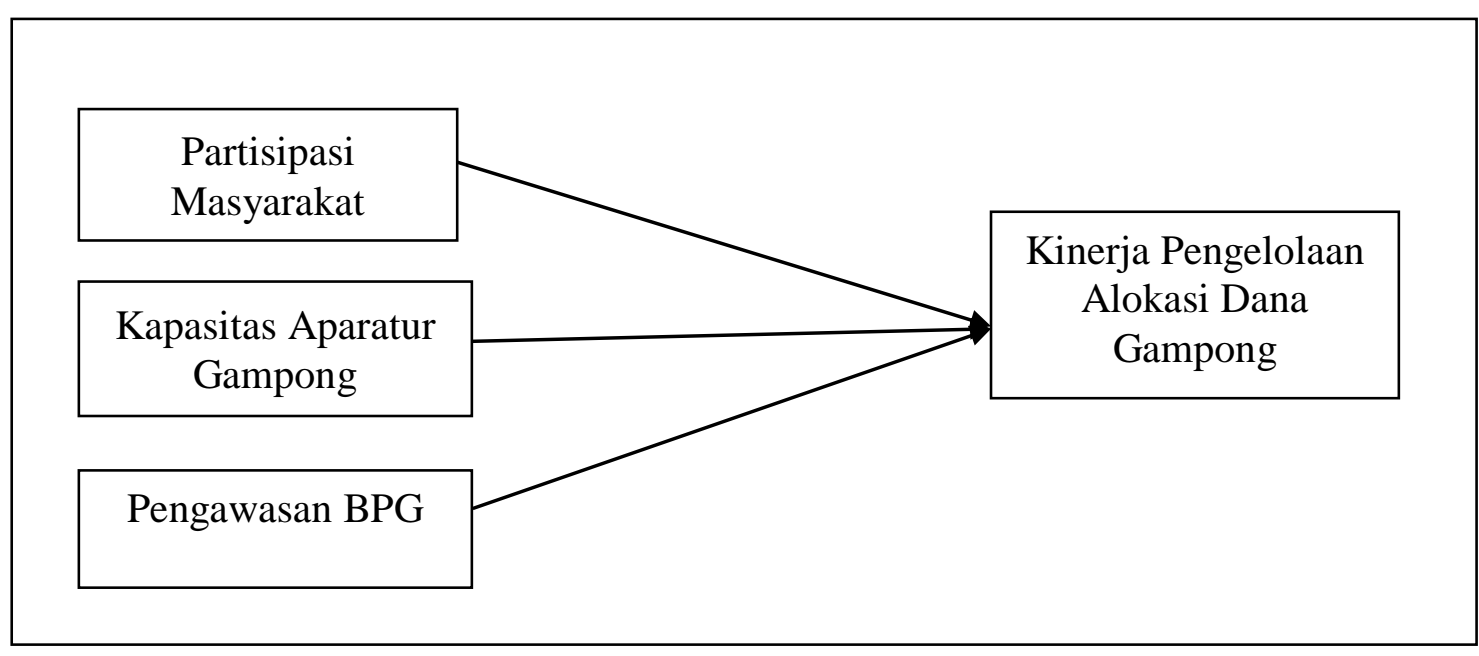




\section{Hipotesis}

$\mathrm{H}_{1}$ : Partisipasi masyarakat, kapasitas aparatur gampong, dan pengawasan BPG, secara bersama-sama bepengaruh terhadap kinerja pengelolaan alokasi dana gampong.

$\mathrm{H}_{2}$ : Partisipasi masyarakat berpengaruh terhadap kinerja pengelolaan alokasi dana gampong.

$\mathrm{H}_{3}$ : Kapasitas aparatur gampong berpengaruh terhadap kinerja pengelolaan alokasi dana gampong.

$\mathrm{H}_{4}$ : Pengawasan BPG berpengaruh terhadap kinerja pengelolaan alokasi dana gampong.

\section{Hasil Pengujian Hipotesis Dan Pembahasan Deskriptif Objek Penelitian}

Data penelitian ini adalah data primer berupa kuesioner. Kuesioner didistribusikan kepada perangkat gampong yang ada di Kecamatan Tangse, Kecamatan Mane dan Kecamatan Geumpang yang terdiri dari 37 Gampong. Pendistribusian kuesioner dilakukan secara langsung oleh peneliti kepada aparatur gampong. Pendistribusian kuesioner dilakukan selama 25 hari (29 April s/d 24 Mei 2018). Jumlah kuesioner yang didistribusikan adalah 185 kuesioner dan hanya 148 kuesioner yang kembali (nilai responden rate $=80 \%$ ) dari 30 gampong. Dengan demikian kuesioner yang digunakan adalah 148 kuesioner atau 80\%. Rincian pendistribusian kuesioner bisa dilihat lebih jelas pada Tabel 1.

Tabel 1

Rincian Pendistribusian Kuesioner

\begin{tabular}{|c|c|c|c|c|}
\hline Responden & Distribusi Kuesioner & Kuesioner Kembali & $\begin{array}{c}\text { Kuesioner Tidak } \\
\text { Kembali }\end{array}$ & $\begin{array}{c}\text { Kuesioner yang } \\
\text { Diolah }\end{array}$ \\
\hline Aparatur Gampong & 185 & 148 & 37 & 148 \\
\hline Persentase & $100 \%$ & $80 \%$ & $20 \%$ & $80 \%$ \\
\hline
\end{tabular}

Sumber: Data Primer, 2018 (diolah)

\section{Karakteristik Responden}

Hasil penyebaran kuesioner kepada 148 responden dari 37 Gampong, dapat dijelaskan bahwa responden dalam penelitian ini sebagian berusia lebih 41-50 tahun yaitu sebanyak 46 orang (31\%) sedangkan yang berusia lebih dari 50 tahun sebanyak 43 orang (29\%). Sementara yang berusia $31-40$ berjumlah 35 orang (24\%) dan yang berusia 21-30 hanya berjumlah 24 orang $(16 \%)$.

Berdasarkan jenjang pendidikan diketahui bahwa mayoritas berpendidikan akhir SMA yaitu berjumlah 117 (79\%). Sementara yang berpendidikan akhir S1 hanya 31 orang (21\%), menunjukkan bahwa responden yang berpendidikan SMA lebih banyak dari responden yang berpendidikan akhir S1.

Karakteristik berdasarkan lama bekerja/masa jabatan, dapat dijelaskan bahwa mayoritas responden didominasi oleh aparatur Gampong yang bekerja selama 4-5 tahun yaitu sebanyak 47 orang (32\%), dan yang bekerja lebih dari 5 tahun seebanyak 39 orang (26\%). Sementara aparatur Gampong yang bekerja yang selama $>1$ tahun hanya 28 orang (19\%) dan apaatur Gampong yang bekerja selama 1-3 tahun berjumlah 34 orang $(23 \%)$.

Statistik Deskriptif Variabel Penelitian

\begin{tabular}{|l|c|c|c|c|c|}
\hline Variabel & $\mathrm{N}$ & Minimum & Maksimum & Rata-rata & Std. Deviation \\
\hline Y & 148 & 4,00 & 5,00 & 4,6635 & 0,36740 \\
X1 & 148 & 4,00 & 5,00 & 4,5439 & 0,38101 \\
X2 & 148 & 4,00 & 5,00 & 4,5272 & 0,37411 \\
X3 & 148 & 4,00 & 5,00 & 4,5609 & 0,36571 \\
Valid N (listwise) & 148 & & & & \\
& & & & & \\
\hline
\end{tabular}

Sumber: Data Primer, 2018 (diolah) 
Diketahui bahwa variabel $\mathrm{Y}$ yaitu kinerja pengelolaan alokasi dana gampong memiliki nilai ratarata sebesar 4,6635. Ini menunjukkan bahwa sebagian besar responden cenderung menjawab sangat setuju untuk pertanyaan yang diajukan berkaitan dengan masalah kinerja pengelolaan dana gampong. Nilai minimum variabel kinerja pengelolaan keuangan desa adalah sebesar 4,00 yang artinya adalah terdapat responden yang menjawab tidak pasti untuk pertanyaan yang diajukan, sedangkan nilai maksimum variabel kinerja pengelolaan keuangan desa adalah sebesar 5,00 yang artinya adalah terdapat responden cenderung menjawab sangat setuju untuk pertanyaan yang diajukan berkaitan dengan kinerja pengelolaan keuangan desa. Variabel X1 yaitu partisipasi masyarakat memliki nilai rata-rata sebesar 4,5439. Ini menunjukkan bahwa sebagian responden cenderung menjawab setuju untuk pernyataan yang diajukan yang berkaitan dengan masalah partisipasi masyarakat. Nilai minimum variabel tersebut adalah sebesar 4,00 yang artinya responden cenderung menjawab setuju untuk pertanyaan yang diajukan, sedangkan nilai maksimumnya adalah sebesar 5,00 yang artinya adalah terdapat responden cenderung menjawab sangat setuju untuk pertanyaan yang diajukan berkaitan dengan partisipasi masyarakat.

Variabel X2 yaitu kapasitas aparatur gampong memiliki nilai rata-rata sebesar 4,5272. Ini menunjukkan bahwa sebagian besar responden cenderung menjawab sangat setuju untuk pertanyaaan yang diajukan mengenai masalah kapasitas aparatur. Nilai minimum variabel kapasitas aparatur gampong adalah sebesar 4,00 yang berarti bahwa terdapat responden cenderung menjawab setuju untuk pertanyaan yang dianjukan, sedangkan nilai maksimum variabel kapasitas aparatur gampong adalah sebesar 5,00 yang artinya terdapat responden cenderung menjawab sangat setuju untuk pertanyaan yang dianjukan berkaitan dengan kapasitas aparatur gampong.

Variabel kualitas pengawasan BPG memiliki nilai rata-rata sebesar 4,5609. Ini menujukkan bahwa sebagian besar responden cenderung menjawab sangat setuju untuk pertanyaaan yang berkaitan dengan masalah pengawasan BPG. Nilai minimum variabel pengawasan BPG adalah sebesar 4,00 yang artinya terdapat responden cenderung menjawab setuju untuk pertanyaan yang dianjukan, sedangkan nilai maksimum variabel kualitas pengawasan BPG adalah sebesar 5,00 yang artinya adalah terdapat responden yang cenderung menjawab sangat setuju untuk variabel pengawasan $\mathrm{BPG}$.

\section{Hasil Pengujian Istrumen \\ Hasil Pengujian Validitas}

Pengujian validitas dilakukan untuk menguji apakah instrumen pengukuran variabel yang digunakan dalam penelitian ini dapat mengukur variabel tersebut secara tepat. Pengujian kualitas data dalam penelitian ini dilakukan secara statistik menggunakan uji pearson product-moment coefficient of correlations dengan nilai signifikansi (nilai kritis) sebesar 5\% dibantu oleh SPSS 23. Apabila nilai total person correlation $>0,161$ atau probabilitas kurang dari 0,05 maka item tersebut valid. Setiap item pertanyaan dikatakan valid jika nilai korelasi hitung > nilai kritis. Variabel yang diuji validitasnya adalah variabel partisipasi masyarakat, kapasitas aparatur gampong, dan pengawasan badan permusyawaratan gampong terhadap kinerja pengelolaan alokasi dana gampong. Hasil pengujian validitas dapat diperhatikan pada Tabel 4.6

Tabel 2

Hasil Pengujian Validitas

\begin{tabular}{|c|c|c|c|c|}
\hline Item Pertanyaan & Variabel & Koefisien Korelasi & Nilai Kritis $r(N=148)$ & Kesimpulan \\
\hline KPAG1 & \multirow{5}{*}{$\begin{array}{c}\text { Kinerja Pengelolaan Alokasi } \\
\text { Dana Gampong }\end{array}$} & 0.775 & 0,161 & Valid \\
\hline KPAG 2 & & 0.779 & 0,161 & Valid \\
\hline KPAG 3 & & 0.737 & 0,161 & Valid \\
\hline KPAG 4 & & 0.806 & 0,161 & Valid \\
\hline KPAG 5 & & 0.796 & 0,161 & Valid \\
\hline PM1 & \multirow{4}{*}{ Partisipasi Masyarakat } & 0.765 & 0,161 & Valid \\
\hline PM 2 & & 0.793 & 0,161 & Valid \\
\hline PM 3 & & 0.802 & 0,161 & Valid \\
\hline PM 4 & & 0.692 & 0,161 & Valid \\
\hline
\end{tabular}




\begin{tabular}{|c|c|c|c|c|}
\hline Item Pertanyaan & Variabel & Koefisien Korelasi & Nilai Kritis r $(\mathrm{N}=148)$ & Kesimpulan \\
\hline KAG1 & \multirow{9}{*}{$\begin{array}{l}\text { Kapasitas Aparatur } \\
\text { Gampong }\end{array}$} & 0.779 & 0,161 & Valid \\
\hline KAG 2 & & 0.737 & 0,161 & Valid \\
\hline KAG 3 & & 0.791 & 0,161 & Valid \\
\hline KAG 4 & & 0.777 & 0,161 & Valid \\
\hline KAG 5 & & 0.763 & 0,161 & Valid \\
\hline KAG 6 & & 0.712 & 0,161 & Valid \\
\hline KAG 7 & & 0.721 & 0,161 & Valid \\
\hline KAG 8 & & 0.743 & 0,161 & Valid \\
\hline KAG 9 & & 0.711 & 0,161 & Valid \\
\hline PBPG1 & \multirow{6}{*}{$\begin{array}{c}\text { Pengawasan Badan } \\
\text { Permusyawaratan Gampong }\end{array}$} & 0.781 & 0,161 & Valid \\
\hline PBPG 2 & & 0.737 & 0,161 & Valid \\
\hline PBPG 3 & & 0.811 & 0,161 & Valid \\
\hline PBPG 4 & & 0.777 & 0,161 & Valid \\
\hline PBPG 5 & & 0.617 & 0,161 & Valid \\
\hline PBPG 6 & & 0.785 & 0,161 & Valid \\
\hline
\end{tabular}

Sumber: Data Primer, 2018 (diolah)

Berdasarkan Tabel 2 dapat dinyatakan semua data valid karena nilai $r$ hitung dari semua item lebih besar dari nilai $r$ tabel. Oleh karena itu semua pernyataan layak dan dapat digunakan pada instrumen dan memiliki validitas konstrak atau terdapat konsistensi internal (internal consistence) yang berarti bahwa data yang diperoleh adalah valid dan dapat digunakan untuk penelitian.

\section{Hasil Pengujian Reliabilitas}

Uji reliabilitas merupakan suatu pengukuran untuk menunjukkan sejauh mana pengukuran tersebut tanpa bias (bebas kesalahan-error free) sehingga menunjukkan akurasi, konsistensi, dan ketetapan dari pengukurannya (Sekaran, 2006:40). Pengukuran reliabilitas terhadap instrumen ini menggunakan teknik Crombach Alpha (a) yang menafsirkan korelasi antara skala yang dibuat dengan semua skala variabel yang ada. Sekaran (2006:182) menyatakan bahwa suatu instrumen dapat dikatakan reliabel bila memiliki keandalan atau alpha diatas 0,60. Variabel yang diuji reliabilitasnya adalah kinerja pengelolaan dana gampong, partisipasi masyarakat, kapasitas aparatur gampong, dan pengawasan badan permusyawaratan gampong. Hasil uji reliabilitas sebagai berikut:

Tabel 3

Hasil Pengujian Reliabilitas

\begin{tabular}{|c|c|c|c|}
\hline Variabel & Crombach Alpha & Nilai Kritis Crombach's Alpha & Keterangan \\
\hline Partisipasi Masyarakat (X1) & 0,761 & 0,60 & Reliabel \\
\hline Kapasitas Aparatur Gampong (X2) & 0,888 & 0,60 & Reliabel \\
\hline Pengawasan BPG (X3) & 0,847 & 0,60 & Reliabel \\
\hline Kinerja Pengelolaan Dana Gampong (Y) & 0,838 & 0,60 & Reliabel \\
\hline
\end{tabular}

Sumber: Data Primer, 2018 (diolah)

Berdasarkan pada Tabe 4.7 di atas, maka dapat disimpulkan bahwa semua variabel memiliki Crombach Alpha di atas 0,60 yaitu partisipasi masyarakat $0,761 \%$, kapasitas aparatur gampong sebesar 0,888\%, pengawasan BPG sebesar 0,847\%, dan kinerja pengelolaan dana gampong sebesar $0,838 \%$. Hal ini menunjukkan bahwa instrumen tersebut memiliki reliabilitas yang sangat baik.

\section{Pengujian Hipotesis}

\section{Model Persamaan Regresi Linear Berganda}

Guna mengetahui pengaruh variabel-variabel independen terhadap variabel dependen maka menggunakan analisis regresi linear berganda dengan bantuan perangkat program SPSS 23 yang secara rinci disajikan pada lampiran. Variabel independen dalam penelitian ini adalah partisipasi masyarakat (X1), kapasitas aparatur gampong (X2), dan pengawasan BPG (Badan Permusyawaratan Gampong). Sedangkan 
variabel dependennya adalah kinerja pengelolaan alokasi dana gampong (Y). Hasil pengujian regresi linear berganda dapat dilihat pada Tabel 4 .

\section{Tabel 4}

Hasil Pengujian Regresi Linear Berganda

\begin{tabular}{|c|c|c|}
\hline \multirow{2}{*}{ Variabel } & \multicolumn{2}{|c|}{$\begin{array}{c}\text { Unstandardized } \\
\text { Coefisients }\end{array}$} \\
\cline { 2 - 3 } & $\boldsymbol{\beta}$ & $\begin{array}{c}\text { Std. } \\
\text { Error }\end{array}$ \\
\hline Konstanta & 1,707 & 0,403 \\
Partisipasi Masyarakat & 0,145 & 0,071 \\
Kapasitas aparatur gampong & 0,459 & 0,084 \\
pengawasan BPG & 0,048 & 0,085 \\
\hline \multicolumn{2}{|c|}{$=0,564$} \\
Koefisien Korelasi (R) \\
Koefisien Determinasi (R $\left.{ }^{2}\right) \quad=0,318$ \\
Adjusted R Square & $=0,304$ \\
\hline
\end{tabular}

Sumber: Data primer, 2018 (diolah)

Hasil output SPSS (coefficient), dapat diperoleh persamaan regresi berganda (multiple regression) sebagai berikut:

$$
Y=1,707+0,145 X_{1}+0,459 X_{2}+0,048 X_{3}+\varepsilon
$$

Berdasarkan hasil analisis yang telah diuraikan sebelumnya dapat diketahui bahwa partisipasi masyarakat $\left(\mathrm{X}_{1}\right)$, kapasitas aparatur gampong $\left(\mathrm{X}_{2}\right)$ dan pengawasan BPG mempunyai pengaruh terhadap kinerja pengelolaan alokasi dana gampong dengan koefisien masing-masing variabel sebesar 0,145 , 0,459 dan 0,048 .

\section{Pengujian Hipotesis Secara Bersama-sama}

Pengujian hipotesis secara bersama-sama dilakukan untuk menguji hipotesis mengenai partisipasi masyarakat, kapasitas aparatur desa, dan pengawasan BPG secara bersama-sama terhadap kinerja pengelolaan dana gampong. Penelitian ini menggunakan kriteria penerimaan dan penolakan hipotesis yaitu jika $\beta_{\mathrm{i}}(\mathrm{I}=1,2,3)=0 ; \mathrm{H}_{0}$ diterima dan jika paling sedikit ada satu $\beta_{i}(I=1,2,3) \neq 0$ : $\mathrm{H}_{0}$ ditolak.

Berdasarkan Tabel 4.12 hasil pengujian pengaruh partisipasi masyarakat, kapasitas aparatur desa, dan pengawasan BPG secara bersama-sama diperoleh bahwa semua koefisien regresi $(\beta)$ masingmasing variabel independen tidak sama dengan nol, dimana nilai koefisien $\beta_{1}=0,145$, nilai koefisien $\beta_{2}=$ 0,459 , dan nilai koefisien $\beta_{3}=0,048$. Menggunakan kriteria penerimaan dan penolakan hipotesis yang telah ditentukan sebelumnya, maka dapat disimpulkan bahwa partisipasi masyarakat, kapasitas aparatur desa, dan pengawasan BPG secara bersama-sama berpengaruh terhadap kinerja pengelolaan alokasi dana gampong, dengan demikian hasil penelitian ini menolak hipotesis nol $\left(\mathrm{H}_{0}\right)$ atau menerima hipotesis alternatif $\left(\mathrm{H}_{\mathrm{A}}\right)$.

Menguji besarnya pengaruh secara bersamasama dapat dilihat pada besarnya koefisien determinasi, yang menjelaskan pengaruh antara variabel independen, berdasarkan tabel 4.12 diperoleh nilai koefisien determinasi $\left(\mathrm{R}^{2}\right)$ sebesar 0,318 . Hal ini menunjukkan bahwa partisipasi masyarakat, kapasitas aparatur desa, dan pengawasan BPG mampu menjelaskan variasi dari variabel kinerja pengelolaan dana gampong sebesar $31,8 \%$ sedangkan sisanya $68,2 \%$ dapat dijelaskan oleh variabel lain yang tidak termasuk dalam penelitian ini.

\section{Pengujian Hipotesis Secara Parsial}

Partisipasi Masyarakat Berpengaruh terhadap Kinerja Pengelolaan Alokasi Dana Gampong

Guna menguji hipotesis kedua yaitu pengaruh partisipasi masyarakat terhadap kinerja pengelolaan alokasi dana gampong menggunakan kriteria penerimaan dan penolakan hipotesis yaitu jika $\beta_{1}=0$; $\mathrm{H}_{0}$ diterima dan jika $\beta_{1} \neq 0 ; \mathrm{H}_{0}$ ditolak. Hasil pengujian terhadap varaibel partisipasi masyarakat (X1) diperoleh nilai koefisien regresi sebesar 0,134 Hal ini menunjukkan bahwa koefisien pengaruh kapasitas aparatur desa terhadap kinerja pengelolaan keuangan desa tidak sama dengan nol $\left(\beta_{1}=0,145\right.$. Dapat diinterprestasiakan bahwa setiap 1 poin peningkatan kapasitas aparatur desa maka secara secara relatif akan meningkatkan kinerjaa pengelolaan alokasi dana gampong sebesar 0,145 poin.

Berdasarkan kriteria penerimaan dan penolakan yang telah ditentukan sebelumnya, dapat disimpulkan bahwa partisipasi masyarakat berpengaruh terhadap kinerja pengelolaan alokasi dana gampong. Dengan demikian hasil penelitian ini menolak hipotesis nol $\left(\mathrm{H}_{0}\right)$ atau menerima hipotesis alternatif $\left(\mathrm{H}_{\mathrm{A}}\right)$.

\section{Kapasitas Aparatur Gampong Berpengaruh terhadap Kinerja Pengelolaan Alokasi Dana Gampong}

Guna menguji hipotesis ketiga yaitu pengaruh kapasitas aparatur gampong terhadap kinerja 
pengelolaan alokasi dana gampong menggunakan kriteria penerimaan dan penolakan hipotesis yaitu jika $\beta_{2}=0 ; \mathrm{H}_{0}$ diterima dan diterima dan jika $\beta_{2} \neq 0 ; \mathrm{H}_{0}$ ditolak. Hasil pengujian terhadap variabel kapasitas aparatur gampong (X2) diperoleh nilai koefisien regresi sebesar 0,459, hal ini menunjukkan bahwa koefisien pengaruh kapasitas aparatur gampong terhadap kinerja pengelolaan alokasi dana gampong tidak sama dengan nol $\left(\beta_{2}=0,459\right)$. Dapat diinterprestasiakan bahwa setiap 1 poin peningkatan kapasitas aparatur gampong maka secara secara relatif akan meningkatkan kinerja pengelolaan keuangan desa sebesar 0,459 poin.

Berdasarkan kriteria penerimaan dan penolakan yang telah ditentukan sebelumnya, dapat disimpulkan bahwa kapasitas aparatur gampong berpengaruh terhadap kinerja pengelolaan alokasi dana gampong. Dengan demikian hasil penelitian ini menolak hipotesis nol $\left(\mathrm{H}_{0}\right)$ atau menerima hipotesis alternatif $\left(\mathrm{H}_{\mathrm{A}}\right)$.

\section{Pengawasan BPG (Badan Permusyawaratan Gampong) Berpengaruh terhadap Kinerja Pengelolaan Alokasi Dana Gampong}

Guna menguji hipotesis keempat yaitu pengaruh pengawasan BPG terhadap kinerja pengelolaan alokasi dana gampong menggunakan kriteria penerimaan dan penolakan hipotesis yaitu jika $\beta_{3}=0 ; H_{0}$ diterima dan jika $\beta_{3} \neq 0 ; H_{0}$ ditolak. Hasil pengujian terhadap variabel pengawasan BPG (X3) diperoleh nilai koefisien regresi sebesar 0,048. Hal ini menunjukkan bahwa koefisien pengaruh pengawasan BGP terhadap kinerja pengelolaan alokasi dana gampong tidak sama dengan nol $\left(\beta_{3}=0,048\right)$. Dapat diinterprestasikan bahwa setiap 1 poin peningkatan pengawasan BPG maka secara secara relatif akan meningkatkan kinerja pengelolaan alokasi dana gampong sebesar 0,048 poin.

Berdasarkan kriteria penerimaan dan penolakan yang telah ditentukan sebelumnya, dapat disimpulkan bahwa pengawasan BPG berpengaruh terhadap kinerja pengelolaan alokasi dana gampong. Dengan demikian hasil penelitian ini menolak hipotesis nol $\left(\mathrm{H}_{0}\right)$ atau menerima hipotesis alternatif $\left(\mathrm{H}_{\mathrm{A}}\right)$.

Tabel 5

Hasil Pengujian Hipotesis

\begin{tabular}{|c|l|l|l|}
\hline Hipotesis & \multicolumn{1}{|c|}{ Hipotesis yang diajukan } & \multicolumn{1}{|c|}{$\boldsymbol{\beta}$} & \multicolumn{1}{|c|}{ Kesimpulan } \\
\hline Hopotesis 1 & $\begin{array}{l}\text { Partisipasi masyarakat, kapasitas aparatur gampong, dan } \\
\text { kualitas pengawasan BPG berpengaruh terhadap kinerja } \\
\text { pengelolanan alokasi dana gampong. }\end{array}$ & $\begin{array}{l}\left(\beta_{1}=0,145 ; 0,459 ;\right. \\
0,048 \quad \beta_{1}(\mathrm{i}=1,2,3) \neq 0\end{array}$ & $\begin{array}{l}\text { Menerima } \\
\text { Hipotesis } \\
\text { Alternatif }\left(\mathrm{H}_{\mathrm{A}}\right) .\end{array}$ \\
\hline Hipotesis 2 & $\begin{array}{l}\text { Partisipasi masyarakat berpengaruh terhadap kinerja } \\
\text { pengelolaan alokasi dana gampong. }\end{array}$ & $\begin{array}{l}\beta_{1}=0,145 \\
\beta_{1} \neq 0\end{array}$ & $\begin{array}{l}\text { Menerima } \\
\text { Hipotesis } \\
\text { Alternatif }\left(\mathrm{H}_{\mathrm{A}}\right) .\end{array}$ \\
\hline Hipotesis 3 & $\begin{array}{l}\text { Kapasitas aparatur gampong berpengaruh terhadap } \\
\text { kinerja pengelolaan alokasi dana gampong. }\end{array}$ & $\begin{array}{l}\beta_{2}=0,459 \\
\beta_{2} \neq 0\end{array}$ & $\begin{array}{l}\text { Menerima } \\
\text { Hipotesis } \\
\text { Alternatif }\left(\mathrm{H}_{\mathrm{A}}\right) .\end{array}$ \\
\hline Hipotesis 4 & $\begin{array}{l}\text { Pengawasan BPG berpengaruh terhadap kinerja } \\
\text { pengelolaan alokasi dana gampong. }\end{array}$ & $\begin{array}{l}\text { Menerima } \\
\beta_{3}=0,048 \\
\beta_{3} \neq 0\end{array}$ \\
& & $\begin{array}{l}\text { Hipotesis } \\
\text { Alternatif }\left(\mathrm{H}_{\mathrm{A}}\right) .\end{array}$ \\
\hline
\end{tabular}

Sumber: Data primer, 2018 (diolah)

\section{Pembahasan}

Pengaruh Partisipasi Masyarakat, Kapasitas Aparatur Gampong, dan Pengawasan BPG terhadap Kinerja Pengelolaan Alokasi Dana Gampong

Berdasarkan hasil pengujian hipotesis 1 menunjukkan nilai koefisien regresi simultan $\beta_{1}$ $(\mathrm{i}=1,2,3) \neq 0$, yang berarti hasil pengujian mendukung hipotesis alternatif, sehingga dapat dinyatakan bahwa partisipasi masyarakat, kapasitas aparatur gampong, dan kualitas pengawasan BPG berpengaruh secara bersama-sama terhadap kinerja pengelolaan alokasi dana gampong. Hasil penelitian menujukkan koefisien korelasi (R) sebesar 0,564 menunjukkan bahwa derajat hubungan (korelasi) antara variabel independen terhadap variabel dependen sebesar 56,4\%. Artinya partisipasi masyarakat, kapasitas aparatur gampong, dan kualitas pengawasan BPG mempunyai hubungan dengan kinerja pengelolaan alokasi dana gampong sebesar $56,4 \%$. 
Pengaruh bersama-sama ditunjukkan oleh nilai koefisien determinasi $\left(\mathrm{R}^{2}\right)$ sebesar 0,318, artinya bahwa kinerja pengelolaan alokasi dana gampong dipengaruhi partisipasi masyarakat, kapasitas aparatur gampong, dan kualitas pengawasan BPG sebesar $31,8 \%$ selebihnya sebesar $68,2 \%$ disebabkan oleh variabel-variabel lain yang tidak termasuk dalam penelitian ini. Dengan adanya partisipasi masyarakat, kapasitas aparatur gampong, dan kualitas pengawasan BPG dapat memberikan suatu perubahan yang baik dalam meningkatkan kinerja pengelolaan alokasi dana gampong pada Kecamatan Tangse, Kecamatan Mane, dan Kecamatan Geumpang di Kabupaten Pidie. Hal ini menunjukkan bahwa semakin baik partisipasi masyarakat, kapasitas aparatur gampong, dan kualitas pengawasan BPG maka akan meningkatkan kinerja pengelolaan alokasi dana gampong pada Kecamatan Tangse, Mane dan Geumpang di Kabupaten Pidie. Hasil penelitian ini sesuai dengan penelitian yang dilakukan oleh Kartika (2012), Asrori (2014), dan Putra (2013).

Kinerja pengelolan keuangan desa merupakan hasil kerja atau prestasi yang dicapai suatu organisasi, daerah, desa/Gampong dalam melaksanakan seluruh kegiatan meliputi perencanaan, pelaksanaan, pelaporan dan pertanggung jawaban keuangan gampong selama 1 tahun periode yaitu mulai dari 1 januari s/d 31 Desember. Kinerja atau Performance merupakan gambaran mengenai tingkat pencapaian pelaksanaan suatu kegiatan, atau kebijakan dalam mewujudkan sasaran, tujuan, visi dan misi organisasi yang dituangkan melalui perencanaan strategis suatu organisasi (Moeheriono, 2012:97).

Guna meningkatkan kinerja pengelolaan alokasi dana gampong perlu adanya pendapat dan partisipasi dari warga desa. Kinerja pengelolaan alokasi dana gampong yang baik dapat dihasilkan dengan meningkatkan pemahaman mengenai pentingnya partisipasi masyarakat dalam mengelola dana gampong. Oleh karenanya, masyarakat harus ikut berpartisipasi dalam menentukan dan mengelola keuangan gampong.

Selain itu, guna meningkatkan kinerja pengelolaan keuangan desa maka pengelolaan keuangan harus dilakukan secara efektif, efisien, ekonomis dan memenuhi pelaporan yang memadai. Kinerja pengelolaan alokasi dana gampong yang baik dapat dihasilkan dengan meningkatkan pemahaman mengenai pentingnya kapasitas aparatur gampong dalam mengelola dana gampong. Oleh karenanya, aparatur gampong harus mempunyi pengetahuan yang lebih banyak baik pengetahuan mengenai bagaimana cara mengelola keuangan akuntansi yang akuntabel dan transparan maupun kemampuan analitisnya.

Peran BPG (Badan Permusyawaratan Gampong) atau yang lebih dikenal di Gampong sebagai Tuha Peut Gampong. Peran BPG yaitu mengawasi jalannya pembangunan Gampong, membahas dan menyetujui APBG (Anggaran Pendapatan Belanja Gampong) termasuk menggali, menghimpun dan menyalurkan aspirasi masyarakat. BPG sebagai badan perwakilan merupakan wahana untuk melaksanakan demokrasi pancasila. Kedudukan BPG dalam struktur pemerintah desa adalah sejajar dan menjadi mitra dari Pemerintaha Desa. Hal ini ditegaskan dalam Undang-Undang No. 32 Tahun 2004 tentang Pemerintah Daerah bahwa pemerintah desa adalah kegiatan pemerintah yang dilaksanakan Pemerintah Desa dan Badan Permusyawaratan Desa.

\section{Pengaruh Partisipasi Masyarakat terhadap Kinerja Pengelolaan Alokasi Dana Gampong}

Hasil pengujian hipotesis kedua menunjukkan bahwa nilai koefisien $\beta_{1}=0,145$ menunjukkan bahwa partisipasi masyarakat berpengaruh terhadap kinerja pengelolaan alokasi dana gampong. Hasil pengujian ini mendukung hipotesis kedua yang telah dirumuskan sebelumnya.

Partisipasi masyarakat memiliki pengaruh positif dan berpengaruh terhadap kinerja pengelolaan alokasi dana gampong. Hal ini menunjukkan bawa semakin tinggi tingkat partisipasi masyarakat tentang pengelolaan alokasi dana gampong maka akan semakin meningkatkan kinerja pengelolaan alokasi dana gampong. Keikutsertaan masyarakat dalam proses pengidentifikasian masalah dan potensi yang ada di masyarakat, pemilihan dan pengambilan keputusan tentang alternatif solusi berguna untuk menangani masalah dalam mengalokasi dana gampong (Isbandi, 2007: 27)

Hasil penelitian ini konsisten dengan hasil penelitian yang dilakukan oleh Kartika (2012), Asni et al. (2013), dan Suwandi (2015) yang menghasilkan kesimpulan bahwa partisipasi masyarakat dalam mengelola ADG adalah hak bagi warga untuk 
menyuarakan, mengakses, dan mengontrol program ADG yang ada di desanya.

\section{Pengaruh Kapasitas Aparatur Gampong terhadap Kinerja Pengelolaan Alokasi Dana Gampong}

Berdasarkan pengujian hipotesis ketiga menunjukkan hasil bahwa kapasitas aparatur gampong berpengaruh terhadap kinerja pengelolaan keuangan desa, dimana nilai koefisien regresi $\beta_{2} .=0,459$. Hasil penelitian ini mendukung hipotesis ketiga yang telah dirumuskan sebelumnya. Hal ini dapat dijelaskan bahwa aparatur gampong melaporkan laporan keuangannya sebagai entitas pelaporan. Salam (2004: 169) mengemukakan bahwa sebagai alat pemerintah yang akan digunakan untuk mencapai tujuan negara yang mempunyai kewajiban untuk melayani semua warga Negara kapasitas aparatur gampong harus memadai.

Hasil penelitian ini menunjukkan bahwa kapasitas aparatur gampong memiliki pengaruh positif dan berpengaruh terhadap kinerja pengelolaan alokasi dana gampong serta dengan hasil penelitian yang dilakukan oleh Jaitun (2013) dan Asrori (2014). Hal ini berarti bahwa semakin berkualitas aparatur desa dalam melaporkan keuangannya maka semakin tinggi pula pengaruhnya terhadap kinerja pengelolaan keuangan desa.

Asrori (2014) yang mengatakan bahwa pencapaian kinerja dipengaruhi oleh kapasitas aparatur desa yang memadai termasuk kemampuan, pengetahuan, pengalaman dan motivasi lingkungan kerja.

Berdasarkan hasil penelitian ini, aparatur desa pada tiga kecamatan di Kabupaten Pidie mayoritas berpendidikan SMA, dari 148 responden yang terdiri dari 37 Gampong, hanya 31 orang (21\%) aparatur Gampong yang berpendidikan akhir S1, sedangkan selebihnya 117 orang (79\%) aparatur Gampong yang berpendidikan akhir SMA. Meskipun aparatur Gampong banyak yang mempunyai latar belakang pendidikan SMA namun sebagian besar mereka telah memahami pengelolaan keuangan dengan baik.

\section{Pengaruh Kualitas Pengawasan BPG (Badan Permusyawaratan Gampong) terhadap Kinerja Pengelolaan Keuangan Desa}

Berdasarkan hasil pengujian hipotesis keempat yang menyatakan bahawa pengawasan BPG berpengaruh terhadap kinerja pengelolaan alokasi dana desa, hal ini sesuai hasil pengujian nilai koefisien regresi $\beta_{3}=0,048$. Hasil ini mendukung hipotesis yang telah dirumuskan sebelumnya. Marigan (2004: 61) menjelaskan bahwa jika pimpinan ingin mengetahui hasil pelaksanaan pekerjaan yang dilakukan pekerja sesuai dengan rencana, perintah, tujuan, kebijakan yang telah ditentukan harus adanya pengawasan yang baik.

Hasil penelitian ini menunjukkan bahwa pengawasan BPG berpengaruh positif terhadap kinerja pengelolaan keuangan desa. Ini berarti bahwa semakin baik pengawasan BPG yang dilakukan maka akan semakin meningkatkan kinerja pengelolaan alokasi dana gampong. Hasil penelitian ini konsisten dengan penelitian yang dilakukan oleh Putra (2013) dan Warsono dan Ruksamin (2014), yang menyimpulkan bahwa adanya hubungan positif antara kualitas pengawasan BPD terhadap kinerja pengelolaan keuangan desa, dimana sebuah desa/Gampong yang memilki kualitas pengawasan yang baik yang dilakukan BPD/Tuha peut Gampong, maka semakin bagus pula kinerja pengelolaan keuangan desa tersebut.

Berdasarkan hasil penelitian ini, pengawasan BPG pada tiga Kecamatan di Kabupaten Pidie mampu mempengaruhi kinerja pengelolaan keuangan desa sebesar 31,8\%. Ini menunjukkan bahwa pengawasan BPG yang ada di tiga Kecamatan di Kabupaten pidie tidak berjalan secara optimal.

\section{Kesimpulan dan Saran \\ Kesimpulan}

Dari hasil pengujian hipotesis dan pembahasan yang telah diuraikan sebelumnya, dapat diambil kesimpulan sebagai berikut:

1) Partisipasi masyarakat, kapasitas aparatur gampong, dan pengawasan BPG berpengaruh secara bersama-sama terhadap kinerja pengelolaan alokasi dana gampong. Hal ini menunjukkan bawa semakin baik partisipasi dan kapasitas aparatur gampong, semakin optimal pengelolaan dana gampong dan semakin efektif pengawasan BPG maka akan semakin meningkatkan kinerja pengelolaan keuangan gampong.

2) Partisipasi masyarakat berpengaruh terhadap kinerja pengelolaan alokasi dana gampong. Hal 
ini menunjukkan bahwa semakin baik partisipasi masyarakat maka akan semakin meningkatkan kinerja pengelolaan alokasi dana gampong.

3) Kapasitas aparatur gampong berpengaruh terhadap kinerja pengelolaan alokasi dana gampong. Hal ini menunjukkan bahwa semakin baik kapasitas aparatur gampong, maka akan semakin meningkatkan kinerja pengelolaan alokasi dana gampong.

4) Pengawasan BPG berpengaruh terhadap kinerja kinerja pengelolaan alokasi dana gampong. Hal ini menunjukkan bahwa semakin optimal kualitas pengawasan BPG, maka akan semakin meningkatkan kinerja pengelolaan alokasi dana gampong.

\section{Saran}

Berdasarkan hasil analisis dan kesimpulan penelitian ini, maka dapat dikemukakan saran-saran sebagai berikut:

1) Penelitian selanjutnya disarankan agar menambah beberapa variabel independen lain yang dapat mempengaruhi kinerja pengelolaan keuangan desa juga dipengaruhi oleh varibel-variabel yang lain selain yang diuraikan dalam penelitian ini.

2) Penelitian ini menggunakan kuesioner untuk mendapatkan informasi data penelitian, jika memungkinkan peneliti selanjutnya dapat melakukan wawancara langsung dengan mahasiswa agar mendapatkan hasil yang lebih detail.

3) Jumlah observasi penelitian hanya tiga kecamatan di satu kabupaten, diharapkan untuk penelitian selanjutnya menggunakan perbandingan beberapa kecamatan atau kabupaten sehingga hasilnya dapat digeneralisasi.

4) Hasil penelitian ini berguna bagi pemerintah Gampong maupun Kabupaten tentang pentingnya kinerja yang baik dalam mengelola keuangan desa, seharusnya di Kecamatan dan Kabupaten lebih ditingkatkan lagi pelatihan berupa pembenahan administrasi untuk mengasah kemampuan aparatur desa dalam mengelola dana gampong.

\section{Daftar Pustaka}

Adi, Isbandi Rukminto. 2007. Perencanaan partisipatoris berbasis aset komunitas: dari pemikiran menuju penerapan. Depok: FISIP UI Press.

Adisasmita, Rahardjo. 2006. Pembangunan Pedesaan dan Perkotaan. Yogyakarta: Graha Ilmu.

Arifin Noor, Drs. H, M, 2007. Ilmu Sosial Dasar, Pustaka Setia, Bandung.

Asni, Fauzi., Maryunani., Sasongko, \& Budi, Dwi. 2013. The Management of the Village Fund Allocation as an Instrument towards Economic Independence Village (Case Studies in 2 villages in Siak Regency, Province Riau). IOSR Journal of Business and Management. (10): 4.

Asrori. 2014. Kapasitas Perangkat Desa Dalam Penyelenggaraan Pemerintahan Desa Di Kabupaten Kudu. Jurnal Bina Praja | Volume 6 Nomor 2 Edisi Juni.

Darise, Nurlan. 2009. Pengelolaan Keuangan Pada Satuan Kerja Perangkat Daerah (SKPD) dan $B L U . J a k a r t a:$ Indeks.

Dwipayana, A. dan Eko, S. 2003. Membangun Good Governance di Desa.Yogyakarta: Ires Press.

Echols, John M and Hassan Shadily. 2000. Kamus Inggris-Indonesia. Jakarta : Gramedia Pustaka Utama.

Fitri. 2015. Kinerja Pemerintah Desa Dalam Pengelolaan Alokasi Dana Desa Pada Desa Vatunonju Kecamatan Biromaru Kabupaten Sigi. E-Jurnal Katalogis, Volume 3 Nomor 1.

Fahmi, I. 2011. Manajemen Kinerja. Alfabeta. Bandung.

Halim, A. 2002. Akuntansi Keuangan Daerah, Edisi 3 Akuntansi Sektor Publik, Salemba Empat, Jakarta.

Halim, A., \& Kusufi, M.S. 2012. Akuntansi Sektor Publik - Akuntansi Keuangan Daerah. Jakarta: Salemba Empat

H.A.W.Widjaja. 2002. Otonomi Daerah Dan Daerah Otonomi. Jakarta: PT.Raja Grafindo Persada.

Heidjrachman, Suad Husnan. 2008. Manajemen Personalia. Edisi 4. Yogyakarta: BPFE. 
Indriantoro \& Supomo. 2002. Metode Penelitian bisnis untuk Akuntansi dan Manajemen. Edisi Pertama. Yogyakarta: BPFE.

Isbandi Rukminto Adi. 2007. Perencanaan partisipatoris berbasis asset komunitas: dari pemikiran menuju penerapan. Depok: FISIP UI Press.

Islami, Ulima. 2007. Kapasitas Aparatur Desa Dalam Tertib Administrasi Desa (Studi Kasus Di Desa Tiuh Toho U Kecamatan Menggala Kabupaten Tulang Bawang). Banda Aceh: Universitas Syiah Kuala.

Jaitun. 2013. Kinerja Aparatur Desa Dalam Penyelenggaraan Pemerintah Desa di Desa Sepala Dalung Kecamatan Sesayap Hilir Kabupaten Tana Tidung. Jurnal Pemerintah Integratif. 1 (1): 13-27.

Kartika, R.S. 2012. Partisipasi Masyarakat Dalam Mengelola Alokasi Dana Desa (Add) Di Desa Tegeswetan Dan Desa Jangkrikan Kecamatan Kepil Kabupaten Wonosobo. Jurnal Bina Praja | Volume 4 No. 3.

Munti, F. dan Fahlevi, H. 2017. Determinan Kinerja Pengelolaan Keuangan Desa: Studi pada Kecamatan Gandapura Kabupaten Bireuen Aceh. Jurnal Akuntansi dan Investasi, Vol. 18 No. 2, Hal: 172-182.

Notoadmodjo, Soekidjo. (2007). Pendidikan dan Prilaku Kesehatan. Jakarta: Rineka Cipta.

Mardiasmo.2013. Perpajakan Edisi Revisi. Yogyakarta: Andi.

Maringan. 2004. Dasar-dasar Administrasi dan Manajemen. Jakarta: Ghalia Indonesia.

Manullang. 2008. Dasar- Dasar Manjemen. Yogyakarta: Ghalia Indonesia (GI)

Mikkelsen. 2003. Dasar-dasarManajemen. Yogyakarta: Gadjah Mada University Press.

Mukhlis. 26 November, 2015. MaTA: Penyimpangan Dana Desa Masih Terus Terjadi. Antara Aceh. Halaman 11.

Serambi Indonesia. 17 Januari, 2017 . Tiga Desa Tak Cairkan DD 2017, halaman. 17.
Mardiasmo. 2009. Akuntansi Sektor Publik. Yogyakarta: Penerbit ANDI.

Natalia, Dewinda Putri. 2010. Pengaruh Komitmen Organisasional dan Peran Manajer Pengelolaan Keuangan Daerah Terhadap Kinerja Manajerial Satuan Kerja Perangkat Daerah. Skripsi. Universitas Diponegoro

Nurcholis, Hanif. 2011. Pertumbuhan dan Penyelenggaraan Pemerintahan Desa. Jakarta: Erlangga.

Putra, Pramana Dian. 2013. Pengawasan Badan Permusyawaratan Desa (BPD) Dalam Pengelolaan Alokasi Dana Desa Di Desa Suliliran Baru Kecamatan Pasir Belengkong Kabupaten Paser, 4: 1501-1512.

Republik Indonesia. Undang-Undang No. 32 Tahun 2004 tentang Pemerintah Daerah

Undang-Undang No. 6 Tahun 2014 tentang Desa.

Undang-Undang No. 72 Tahun 2014 tentang Desa.

Undang-Undang_Nomor 14 Tahun 2015 Tentang Anggaran Pendapatan dan Belanja Negara Tahun Anggaran 2016.

Qanun Kabupaten Pidie No. 8 Tahun 2011 tentang Pemerintahan Gampong. Qanun Kabupaten Pidie No. 3 Tahun 2011 tentang Pemerintahan Gampong.

Peraturan Menteri Dalam Negeri No. 113 Tahun 2014 tentang Pengelolaan Keuangan Desa.

Peraturan Pemerintah Republik Indonesia No 60 Tahun 2014 tentang Dana Desa yang Bersumber dari Anggaran Pendapatan dan Belanja Daerah.

Peraturan Pemerintah Republik Indonesia No 22 Tahun 2015 tentang Dana Desa yang Bersumber dari Anggaran Pendapatan dan Belanja Daerah. 


\section{Peraturan Menteri Dalam}

Negeri No. 37 Tahun 2017 tentang Pedoman Pengelolaan Dana Desa.

Salam, D.S., 2004. Manajemen Pemerintahan Indonesia, Djambatan, Jakarta.

Siagian, Sondang P. 2010. Manajemen Strategis. Total Quality Management. Jakarta: Haji Masagung.

Slamet, Margono. 2003. "Pemberdayaan Masyarakat." Dalam Membetuk Pola Perilaku Manusia Pembangunan. Disunting oleh Ida Yustina dan Adjat Sudradjat. Bogor: IPB Press.

Sekaran, Uma \& Roger Bougie. 2013. Research Method for Business. Sixth Edition. Italy: Printer Trento Srl.

Sekaran, Uma. 2006. Research Methode for Business: Metodologi Peneltian untuk Bisnis Buku 1. Edisi Empat. Jakarta: PT. Bumi Aksara.

Siagian, Sondang P. 2011. Organisasi, Kepemimpinan, dan perilaku organisasi. Jakarta: Bumi Aksara

Soedarmayanti. 2007. Sumber Daya Manusia dan Produktivitas Kerja. Bandung: Penerbit Mandar Maju.

Soeprapto Riyadi. 2010. The Capacity Building For Local Government Toward Good Governance, World Bank.

Sugiyono. 2013. Metode Penelitian Pendidikan Pendidikan Pendekatan Kuantitatif, Kualitatif, dan $R \& D$. Bandung: ALFABETA.

Sumardi. 2010. Manajemen Sumber Daya Manusia. Jakarta: Bumi Aksara.

Suryukoco. 2010. Peningkatan Kapasitas Pemerintah Desa. Melalui https://suryokocolink.wordpress.com diakses pada [29/1/2017].

Suwandi. 2015. Partisipasi masyarakat dalam pelaksanaan Alokasi Dana Gampong (ADG) di Kantor Gampong Suka Damai Kecamatan Muara Badak Kabupaten Kutai Kertanegara. Jurnal Administrasi Negara. 3(4). 1098-1108.

Suwondo, L.M. Paramitha, \& Tjahjanulin Domai. 2013. Kinerja Aparat Pemerintah Desa Dalam Rangka Otonomi Desa (Studi di Desa Gulun,
Kecamatan Maospati, Kabupaten Magetan JAP: Jurnal Administrasi Publik. 1 (4): 91-100.

Subagyo, Pangestu. 2003. Statistik Induktif Edisi 4. Yogyakarta: BPFE.

Sutoro, Eko.2003. Membangun Good Governance di Desa. Yogyakarta : IRE Press. 